\title{
"SOU POMBAGIRA DE UMBANDA, NÃO ME CONHECE QUEM NÃO QUER...": IMAGENS DE POMBAGIRA NA MPB ${ }^{1}$
}

\section{"SOY POMBAGIRA DE UMBANDA, NO ME CONOCE QUIEN NO TIENE GANAS ...": IMÁGENES DE POMBAGIRA EN LA MÚSICA POPULAR BRASILEÑA}

\author{
“I'M AN UMBANDA POMBAGIRA; ONLY THOSE WHO DON'T WANT TO DON'T KNOW ME": \\ POMBAGIRA IMAGES IN BRAZILIAN POPULAR MUSIC
}

Aleksandra Stambowisky de Carvalho* Secretaria Municipal de Educação do Rio de Janeiro

Maria Cristina Giorgi ** CEFET | Rio de Janeiro

Poliana Coeli Costa Arantes ***

Universidade do Estado do Rio de Janeiro

RESUMO: Neste artigo temos como objetivo analisar modos de produção de sentidos em torno da construção da imagem de figura muito conhecida nas religiões afro-brasileiras, a Pombagira. Para tanto, discutimos três canções da Música Popular Brasileira, bastante citadas nos terreiros de Umbanda, partindo de uma perspectiva dialógica e polifônica de linguagem (BAKHTIN, 2011). Observamos que as imagens configuradas pelas letras das canções produzem lugar que desqualifica a figura da Pombagira,

\footnotetext{
${ }^{1}$ Este trabalho é um recorte de pesquisa de mestrado intitulada Na boca de quem não presta?: pontos cantados de Pombagira, uma proposta de análise, realizada por Aleksandra Stambowisky de Carvalho, no Programa de Pós-Graduação em Relações Etnico-raciais do Centro Federal de Educação Tecnológica Celso Suckow da Fonseca - Cefet/RJ em 2016, orientada pela professora Dra. Maria Cristina Giorgi e coorientada pela professora Dra. Poliana Coeli Costa Arantes.

* Mestra em Relaçoes Étnico-raciais pelo Centro Federal de Educação Tecnológica Celso Suckow da Fonseca, graduada em História pela Universidade Estácio de Sá,é docente nos anos iniciais da educação básica, na secretaria Municipal do Riode Janeiro.E-mail: aleksstambowisky@hotmail.com.

** Doutora em Letras pela Universidade Federal Fluminense, desde 2005 , é docente do Cefet/RJ, onde atua no Ensino Médio e Técnico, nos Programas de Pós-Graduação em Relaçóes Étnico-Raciais e Filosofia e Ensino e coordena o curso lato sensuem Relaçóes Étnico-Raciaise Educação. E-mail:cristinagiorgi@gmail.com.

*** Doutora em Linguística (2013) pela Universidade Federalde Minas Gerais, atualmente é Professora adjunto de Língua Alemã da Universidade do Estado do Rio de Janeiro e atua no Programa de Pós-Graduacão em Letras (Mestrado e Doutoradoem Linguística). do Núcleode Análisedo Discurso (NAD-UFMG). E-mail: polianacoeli@yahoo.com.br.
} 
sobretudo porque a ela se inscrevem sentidos depreciativos que, ao denunciar sua não hegemonia, confirmam a hegemonia de outrem, uma vez que a linguagem produz relações e não atributos.

PALAVRAS-CHAVE: Pombagira. MPB. Polifonia. Dialogismo.

RESUMEN: En este artículo tenemos como objetivo analizar modos de producción de sentidos en torno a la construcción de la imagen de figura muy conocida en las religiones afrobrasileñas, la Pombagira. Para ello, discutimos tres canciones de la Música Popular Brasileña, bastante citadas en los terreros de Umbanda, desde una perspectiva dialógica y polifónica de lenguaje (BAKHTIN, 2011). Se observa que las imágenes configuradas por las letras de las canciones producen lugar que descalifica la figura de la Pombagira, sobre todo porque a ella se otorgan sentidos despectivos que, al denunciar su no hegemonía, confirman la hegemonía de otro, una vez que el lenguaje produce relaciones y no atributos.

PALABRAS CLAVE: Pombagira. Música Popular Brasileña. Polifonía. Dialogismo.

ABSTRACT: In this paper we wish to analyze meaning-making processes which take place around the construction of a well-known figure of Afro-Brazilian religions: the Pombagira. In order to do so, we present three Brazilian Popular Music songs which are frequently mentioned in Umbanda centers, starting from a dialogical and polyphonic view of language (BAKHTIN, 2011). We observe that the images configured by the lyrics of the songs produce a place that disqualifies the figure of the Pombagira, especially because it inscribes depreciative senses that, denouncing their non-hegemony, confirm the hegemony of another, since language produces relations and not attributes

KEYWORDS: Pombagira. Brazilian Popular Music. Polyphon. Dialogism.

\section{INTRODUÇÃO}

Exu da meia noite, Exu da madrugada.

Oi salve, salve o povo da encruza.

Mas sem Exu não se faz nada. (Ponto de Exu)

A música popular brasileira (MPB) é inegavelmente uma das mais importantes manifestações artístico-culturais do Brasil, que, além de apreender uma diversidade de aspectos da vida cotidiana dos seus trabalhadores, é capaz de captar transformações nas relações de âmbito econômico, social, político e ideológico, funcionando como fonte documental para a produção de conhecimento científico, sobretudo quando se aborda a vida social dos trabalhadores (PINA, 2014). Com base em trabalhos diversos, como os de Moura (1983), Sodré (1979) e Sandroni (2001) entendemos ser incontestável o papel da MPB como difusora do mundo religioso afro-brasileiro, mais especificamente a umbanda e o candomblé, como já apontado.

Considerando essas relações, nossa proposta neste artigo é elaborar um percurso de análise baseado nas concepções de linguagem preconizadas por Bakhtin e Maingueneau, tendo como foco as imagens de Pombagira encontradas nas canções da MPB selecionadas como corpus desta pesquisa. Nosso intuito é resgatar a composição das estratégias enunciativas envolvidas no processo de construção de imagens da Pombagira e elucidar relações interessantes entre os modos de dizer e de dialogar com outras vozes convidadas para compor as imagens dessa figura feminina de religiões de matrizes africanas no Brasil. Tal figura congrega antíteses em seu modo de se apresentar que acabam reafirmando o lugar menosprezado atribuído às mulheres.

Para resgatar a filiação de Pombagira, buscaremos autores, tais como Prandi, Augras, Capone, Silva, Barros e Simas, que discorrem sobre o status que Pombagira adquiriu na sociedade do século XX e nos cultos religiosos africanos, vinculando a ela uma imagem de mulher transgressora e não merecedora de certos benefícios ou lugares não autorizados a ocupar.

As três canções que constituíram o corpus desta pesquisa: "Moça bonita" (1976), de Jair Amorim e Evaldo Gouveia; "Sob medida" (1979), de Chico Buarque de Hollanda e "Coisa feita" (1982), de João Bosco e Aldir Blanc, foram escolhidas tendo como base 
pesquisa de mestrado realizada pelas autoras, pautada em estudos de Prandi, sendo apresentado neste artigo um recorte da discussão realizada no referido trabalho.

Nosso artigo está dividido em seções que buscaram discorrer sobre os temas supracitados de modo teórico nas seções 2, 3 e 4 e, na seção 5, foram apresentadas as análises realizadas com base nas discussões teóricos estabelecidas.

A seguir, discorremos sobre os conceitos de linguagem utilizados como ponto de partida para as análises.

\section{ENCRUZILHADAS POLIFÔNICAS E DIALÓGICAS}

Partimos de uma concepção dialógica e polifônica de linguagem de acordo com Bakhtin (2001), que estabelece que toda compreensão é ativamente responsiva, dado que "[...] o próprio falante está determinado precisamente a essa compreensão ativamente responsiva: ele não espera, por assim dizer, que apenas duble o seu pensamento em voz alheia, mas uma resposta, uma concordância, uma participação, uma objeção, uma execução, etc.” (BAKHTIN, 2011, p. 272).

Desse modo, afastamo-nos de teorias linguísticas baseadas em conceitos estruturalistas de comunicação preconizados por Jackobson (1979), que estabelecem uma linguagem vista como um código gerado por um Locutor e decodificado por um Receptor; a linguagem que possui um conteúdo a priori, cuja ênfase excessiva numa leitura informacional pode criar o efeito de neutralizar relações existentes entre os interlocutores para a produção dos sentidos.

Inseridas, pois, em concepção polifônica de linguagem que admite a presença de distintas vozes em uma única enunciação, apoiamo-nos na leitura de Ducrot (1987) sobre a heterogeneidade enunciativa feita por Maingueneau (1997), que diferencia locutores de enunciadores. Segundo os autores, "locutor" seria aquele que se apresenta como responsável pelo seu enunciado, mas, como aponta Mainguenau (1997, p. 76) "trata-se de uma ficção discursiva que não coincide necessariamente com o produtor físico do enunciado".

Os enunciadores, por sua vez, conforme o autor (1997, p.77) "são seres cujas vozes estão presentes na enunciação sem que lhes possa, entretanto, atribuir palavras precisas; efetivamente, eles não falam, mas a enunciação permite expressar seu ponto de vista”. Nesse sentido, o locutor pode pôr em cena diversas posições, inclusive diferentes da sua, em seu próprio enunciado.

Para Bakhtin (2004, p. 114) , a concepção dialógica da linguagem pode ser observada em todas e quaisquer enunciações, já que a expressão verbal é, em sua totalidade, socialmente dirigida: "antes de mais nada, ela é determinada da maneira mais imediata pelos participantes do ato de fala, explícitos ou implícitos, em ligação com uma situação bem precisa; a situação dá forma à enunciação [...]". Sendo assim, ressaltamos que nossas análises têm como pressuposto a perspectiva discursiva de linguagem discutida acima e não a informacional.

A fim de designar esta reversibilidade essencial entre as duas faces do discurso, social e textual, Maingueneau (1997) reformula um termo de M. Foucault, denominado "prática discursiva", integrando a ele, além da "formação discursiva" - que se configuraria como lugares institucionais passíveis de serem ocupados por um sujeito de enunciação -, a "comunidade discursiva” - que seria um grupo ou uma organização de grupos no interior dos quais "são produzidos, gerados os textos que dependem da formação discursiva" (MAINGUENEAU, 1997, p. 56).

\section{ESSA TAL MPB...}

Passando da teoria linguística, para as análises musicais, continuamos nos associando a Bakhtin (2006, p. 15), que compreende a palavra como arena onde se confrontam os valores sociais contraditórios. Como consequência, a comunicação verbal implica conflitos, relações de dominação e de resistência e adaptação ou resistência à hierarquia. 
Não foi diferente o percurso da música no Brasil em meados do fim do século XIX e início do século XX, pois, sgeundo Sovic (2000, p. 250) "a música (e o uso musical de sons) era, ao mesmo tempo, o que mais apelava aos sentidos e o que mais se prestava a trocas e misturas entre tradições europeias e afro-brasileiras". Nesse sentido, consideramos que a MPB se constitui por fluxos e refluxos de diversos complexos culturais, que exprimem e exploram as relações e limites entre sagrado, profano, erudito e popular. Conforme Sovik (2000, p. 252), as primeiras experiências musicais brasileiras giravam em torno do campo religioso, das óperas, valsas e polcas, mas também dos cantos de ameríndios e africanos escravizados.

De acordo com Prandi (2005, p. 3), a musicalidade que se apresenta como parte integrante dos cultos afro-brasileiros é, ao mesmo tempo, elemento constitutivo do cotidiano negro, e, em sua concepção, preservou-se no Brasil um dos mais ricos filões culturais da África: a música, mais especificamente a música sacra, com seus ritmos, instrumentos de percussão e formas de composição poética.

Prandi registrou a proximidade entre a música sacra dos bantos (Congo-Angola) e o samba, nos apresentando a seguinte definição para este ritmo:

Entoando letras em línguas rituais de origem banta, hoje muito deturpada e misturada a palavras em português, soando os tambores com as palmas das mãos e dedos, enquanto os iorubás e fons-descedentes o fazem com varetas, os candomblés angola e congo, como são chamados os templos banto, cantam um tipo de música que soa muito familiar aos ouvidos dos não-iniciados. Pois foi justamente da música sacra desse candomblé banto que mais tarde se formou, no plano da cultura profana do Rio de Janeiro, um gênero de música popular que veio a ser importante fonte da identidade nacional brasileira nos decisivos anos 30 do século XX: o samba. (PRANDI, 2005 , p. 4)

Como destacado pelo autor, a familiaridade entre Candomblés e música popular demarca traços das heranças afro-brasileiras, em especial da religiosidade, na identidade nacional, a despeito dos impactos impressos pela política de branqueamento racial e cultural em nossa população.

Diversos estudos contemporâneos abordam a reconstrução do debate racial desenvolvido no Brasil no fim do século XIX e início do XX, dentre os quais destacamos as obras de Schwarcz (1993) e Munanga (1999). Conforme Costa, "[...] tais trabalhos convergem ao indicar que esse debate caracteriza-se pela "expressão do ceticismo então dominante quanto às possibilidades de se construir uma nação progressista nos trópicos, uma vez que a população era constituída em grande medida de negros e mestiços.” (COSTA, 2001, p. 145).

Partindo dessa reflexão, percebemos as preocupações demonstradas pelo Estado brasileiro no tocante às origens "mestiças" de sua população, menos valorizadas em detrimento do privilégio atribuído às matrizes europeias, resultando em implantação de políticas culturais, linguísticas e sociais que contribuíram para a marginalização do negro e das matrizes culturais africanas no Brasil. Medidas que desconsideravam a valorização dos saberes, vivências e experiências das populações ameríndias, africanas e afro-brasileiras concretizam-se como resultado dessas ações.

A incorporação de elementos identitários dessas populações no cenário nacional deu-se timidamente, por meio da implementação da política de nacionalização criada pelo Estado Novo, no governo de Getúlio Vargas, cuja ideia central era construir uma identidade nacional para o país, passando pelos diferentes campos de atuação: política, cultural, social, educacional:

Nessa época, as reformas políticas e econômicas, que ficaram conhecidas como período do Estado Novo, buscavam estabelecer bases de um Estado 'genuinamente' nacional. Isso incluía a valorização e promoção de práticas culturais 'brasileiras' capazes de congregar o sentimento de unidade nacional. Essas proposições encontram na radiodifusão o melhor meio de propaganda e divulgação. Operando de forma seletiva sobre alguns elementos da cultura afro-brasileira, promoveu-os ao status de valores nacionais. (AMARAL; SANTOS, 2006, p. 199) 
É nesse sentido que podemos entender a MPB como um mecanismo de difusão de discursos identitários, não raramente tangenciados por preconceitos no que se refere às influências afro-ameríndias e seus signos. Não obstante aos estereótipos, destacamos a força da oralidade e das relações estabelecidas com a musicalidade por essas populações, forjando um ethos musical brasileiro. Para tal, apoiamos nossa argumentação nas palavras do historiador Luiz Antonio Simas (informação oral ${ }^{2}$ ) ao asseverar que, contrariando os esforços da elite brasileira, "onde o negro foi economicamente escravizado, culturalmente foi ele o agente civilizador". Fato facilmente identificado por meio dos costumes, crenças, gostos e, especificamente, pelo modo como vivemos nossas experiências musicais.

A MPB é, de acordo com Sovik (2000), o que o Brasil tem de mais distinto, singular. Entende a autora que essa afirmação é um consenso na mídia e no pensamento corrente de grande parte da população. Retomando as palavras de José Miguel Wisnik, afirma que a música popular teria auxiliado na construção da educação sentimental do brasileiro. A esse respeito,

[...] a música popular é para o Brasil assim como a gastronomia é para a França - todos tomam uma posição arrazoada a respeito. É um campo em que a cultura erudita e a popular se polarizam e se mesclam. Há uma tradição com variantes regionais, conhecimento prático e teórico, talentos e habilidades amplamente desenvolvidos, e o hábito de discernimento e crítica. Por outro lado, como parte do cotidiano brasileiro, prensada entre o nacional e o estrangeiro, o industrial e o artesanal, a música popular constitui o discurso identitário brasileiro que mais frequentemente se atualiza, com novas composições e discursos midiáticos. (SOVIK, 2000, p. 247)

Entendemos que, ao estabelecer tal reflexão, Sovik destaca a relevância da MPB no cenário cultural nacional, suas perspectivas afetivas e pedagógicas, além de alguns dos tensionamentos que compõem o campo. Contudo, em que medida essa ferramenta pedagógica poderia colaborar para a descristalização e desnaturalização de discursos que desqualificam quaisquer influências não europeias e, ao mesmo tempo, incentivar as produções de perspectivas culturais emancipadoras?

Se o fluxo do hibridismo sociocultural forjou nossa identidade e revelou a capacidade de resistência e negociação das populações subalternizadas, não podemos desconsiderar que o processo de emancipação dessas populações vem sendo lentamente construído por meio de inúmeras disputas e embates. Como asseverado anteriormente por Amaral e Santos (2006, p. 199), a política de nacionalização operou de forma seletiva sobre alguns elementos da cultura afro-brasileira, promovendo-os ao status de valores nacionais.

Essa seletividade fomentou a incorporação de elementos como o samba, a capoeira e a feijoada, que passaram a figurar no imaginário popular como expressão do nacional (SCHWARZ, 2012). O discurso identitário nacional produziu também algumas personagens populares como o malandro, a mulata, o doce e o submisso Pai João. Entretanto, essa produção implicou um reforço pedagógico na busca pela adaptação destes aos paradigmas modernos. Nessa perspectiva, podemos observar uma suposta ascensão do mestiço e o desenvolvimento do mito da democracia racial.

Por fim, na representação vitoriosa dos anos 30, o mestiço transformou-se em ícone nacional, em um símbolo de nossa identidade cruzada no sangue, sincrética na cultura, isto é, no samba, na capoeira, no candomblé e no futebol. Redenção verbal que não se concretizou no cotidiano, a valorização do nacional é acima de tudo uma retórica que não tem contrapartida na valorização das populações mestiças discriminadas. Nesses termos, entre o veneno e a solução, de descoberta a detração e depois exaltação, tal forma extremada e pretensamente harmoniosa de convivência entre os grupos foi, aos poucos, sendo gestada como um verdadeiro mito de Estado. (SCHWARZ, 2012, p. 180)

Como destacado pela autora (2012, p. 180), "a valorização do nacional é acima de tudo uma retórica que não tem contrapartida na valorização das populações mestiças discriminadas”. Assim, a veiculação de imagens resignadas, submissas e moldadas aos padrões vigentes buscou suprimir revoltas e naturalizar históricos violentos e desiguais derivados do processo de escravização, por meio de

${ }^{2}$ Palestra ministrada por Simas em ocasião do I Seminário Internacional Fela Kuti, na UERJ. Disponível em https://youtu.be/4ZCCWpmzJb8. Acesso em: 09 set. 2016

Fórum linguistic., Florianópolis, v.16, n.4, p.4167-4180, out./dez.2019. 
imagens como a de Pai José e a do malandro. O samba "O bonde de São Januário" configurou uma dessas imagens. Escrito por Ataulfo Alves e Wilson Batista em 1940, a letra original exaltava a imagem subversiva do malandro. Porém, ao ser submetida a avaliação do DIP (Departamento de Imprensa e Propaganda), tornou-se uma aclamação ao trabalho.

\author{
Quem trabalha \\ É quem tem razão \\ Eu digo e não tenho medo de errar \\ O Bonde São Januário \\ Leva mais um operário \\ Sou eu que vou trabalhar \\ Antigamente \\ Eu não tinha juízo \\ Mas resolvi garantir \\ meu futuro \\ Vejam vocês \\ Sou feliz \\ vivo muito bem \\ A boemia \\ Não dá camisa \\ A ninguém \\ É, vivo bem \\ (ALVES; BATISTA, 1940)
}

Este texto é um exemplo de como a linguagem em lugar de apenas representar o mundo, claramente nele intervém, pois falar é intervir no mundo, "dizer é fazer", como já preconizava Austin (1990). Em meio aos investimentos do Estado para disciplinarização de corpos e mentes - sobretudo os femininos - um imaginário afrontou o discurso moralizante das décadas de 20 e 30 do século XX. Era Pombagira que preenchia as encruzilhadas com sua presença sensual. Mas afinal, o que ela representa?

Entendemos que essa resposta dialoga com o papel da docilização de corpos em uma sociedade disciplinar que, segundo Foucault (2004) começa a se organizar entre os séculos XVII e XVIII, submete a sociedade como um todo e se constrói por meio de mecanismos que enquadram a existência dos indivíduos na sua singularidade. O poder que individualiza tem como instrumento a vigilância permanente e classificatória que propicia distribuir, julgar, medir - criando modos de vigiar o dia a dia das pessoas, bem como seus comportamentos e atividades e, por conseguinte, utilizá-los ao máximo, fabricando, de acordo com Foucault corpos submissos e exercitados; enfim, corpos dóceis, que já aprenderam que precisam aquiescer para ser excelentes (FOUCAULT, 2004, p. 181).

\title{
4 QUEM É A BELA DAMA?
}

Conforme Capone (2007), Arthur Ramos teria sido o primeiro a citar o termo Pombagira, fato acontecido em uma matéria sobre batidas policiais, publicado em "O jornal" de 12 de outubro de 1938. Assim, a imagem de Pombagira encontra-se diretamente relacionada ao início do século XX, à repressão institucional e aos cultos denominados macumbas cariocas. Rituais híbridos que mesclavam raízes dos Candomblés, do Catolicismo popular e do Espiritismo.

É importante observar que esse primeiro registro reitera argumentos como os de Schwarcz (2012) acerca da marginalização das populações subalternizadas, bem como o seu epistemicídio ${ }^{3}$ (CARNEIRO, 2005). São identidades, culturas, crenças e vivências achatadas em detrimento de uma perspectiva etnocêntrica. É nesse lugar que localizamos a Pombagira, entidade rotineiramente representada como uma mulher leviana, libertina e desviante.

${ }^{3}$ Conforme a filósofa Sueli Carneiro, entende-se como epistemicídio a desvalorização, negação ou apagamento das contribuições do continente africano e da diáspora africana ao patrimônio cultural da humanidade; a ocultação da contribuição negra no saber. 
Segundo Prandi "Pombagira é o espírito de uma mulher (e não o Orixá) que, em vida, teria sido uma prostituta ou cortesã, mulher de baixos princípios morais, capaz de dominar os homens por suas proezas sexuais, amante do luxo, do dinheiro, e de toda sorte de prazeres." (PRANDI 1996, p. 140).

O autor humaniza a entidade afirmando-a como "o espírito de uma mulher", e leva a um distanciamento entre sua imagem e possíveis sacralizações, algo indicado pela expressão "não é Orixá" e por sua estratégia enunciativa que a relaciona à prostituição, a baixos princípios morais e aos prazeres mundanos. Ainda de acordo com o autor: "Pombagira é um Exu, ou melhor, um Exumulher, como ela mesma gosta de ser chamada. Como Exu, ela compõe um riquíssimo e muito variado panteão de diabos, em que ela não somente aparece como um dos Exus, mas é também casada com pelo menos um deles." (PRANDI, 1996, p. 144).

A vinculação desse feminino ao diabo judaico-cristão remete-nos ao processo de colonização da África e, posteriormente, à escravização das populações afro-ameríndias e seus descendentes, exemplificando o impacto da cultura eurocêntrica sobre estas. Em nossa visão, tal ação colabora para a construção de um feminino marcado pela sexualidade, poder e violência, que

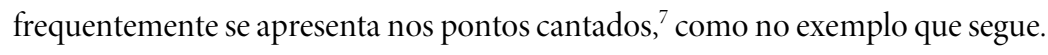

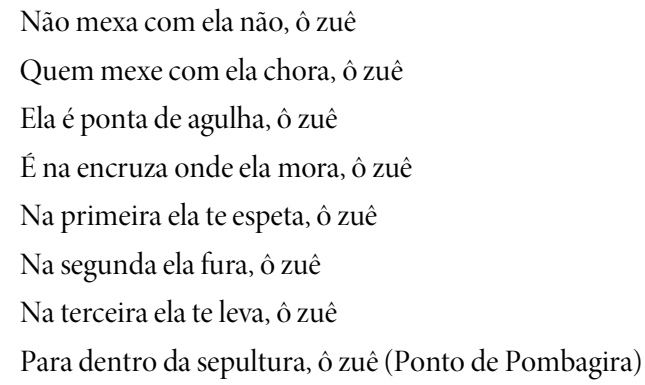

Augras (2000, p. 31) afirmou que, chegando ao Brasil em 1961, encontrou o culto da Pombagira bem estabelecido no Rio de Janeiro, o que a levou a questionar a escassez de seus registros. Para a autora, Pombagira é uma criação carioca que surge em contraste com as figuras femininas dessexualizadas da religião Umbandista, em especial à imaterialidade de Iemanjá - desafricanizada, espiritualizada, mãe boa, "vibração do mar".

Conforme a autora, haveria uma relação entre a entidade e as Mães-ancestrais africanas conhecidas como Yamins, sendo estes femininos convergentes (AUGRAS, 2000), analogia que gerou severas críticas por parte de Capone (2004), que compreendia a subtração desse espírito dos cultos sincréticos e "degenerados" das macumbas cariocas como expressão de uma visão preconceituosa sobre os mesmos.

Como podemos observar, a associação desse espírito à ideia de degeneração dá-se em diferentes perspectivas, seja em virtude do ambiente religioso no qual seu culto foi estabelecido ou pelo fato de seu ethos encarnar uma identidade essencialmente híbrida e subalternizada.

Pombagira, Bombo gira, pombajira; muitas são as grafias do nome dessa entidade. De acordo com Simas, a origem etimológica da palavra deriva:

[...] dos cultos angolo- congoleses aos inquices. Uma das manifestações do poder das ruas nas culturas centroafricanas é o inquice Bombojiro, ou Bombojira, que para muitos estudiosos dos cultos bantos é o lado feminino de Aluvaiá, Mavambo, o dono das encruzilhadas, similar ao Exu iorubá e ao vodum Elegbara dos fons. Em quimbundo, pambu-a-njila é a expressão que designa o cruzamento dos caminhos, as encruzilhadas. Mbombo, no quicongo, é portão. Os portões são controlados por Exu. (SIMAS, 2016, numeração irregular) 
No fragmento acima, vemos novamente a ligação entre Exu e Pombagira. Cabe ressaltar que as tais relações não raramente foram compreendidas como subordinação ao masculino, como podemos observar em

\author{
Padilha é rainha \\ ela é rainha é \\ $\mathrm{Na}$ fé de Exu Caveira \\ $\mathrm{Na}$ fé de Lúcifer. (Ponto Cantado de Pombagira)
}

Nessa concepção, a nobreza e o poder de Pombagira derivam de sua relação com o masculino. Por meio dele, sua imagem ganha prestígio e solidez. Essa subordinação está presente em toda a ritualística da maioria dos terreiros de Umbanda e Quimbanda, sendo Exu o responsável por outorgar à Pombagira a permissão para o trabalho.

Os debates historiográficos acerca dessa entidade estão longe de um consenso. Entre os trabalhos de maior relevância sobre a temática, destacamos as contribuições de Barros, autora que define Pombagira como "uma (re)elaboração de um feminino recalcado" (2010, p. 184), afirmação que deriva de um levantamento das possíveis continuidades desse feminino, retomando ao período Paleolítico (17.000 - 4.000 a.C.) a partir da leitura de trabalhos arqueológicos com esculturas femininas.

Barros (2010) é uma das vozes a tensionar as relações e os papéis de gênero desempenhados pela entidade ao asseverar que "ao lado dos Exus, nem atrás nem na frente, encontramos as Pombagiras" (2015, p. 27) e que elas "[...] vestiram roupas de mulheres transgressoras para 'virem ao mundo', mas mais do que isso, revelam que estão nos corpos femininos, abrangem a 'mulher', dizem ser 'mulher', dizem proteger a 'mulher' e reivindicam um espaço de autoridade e respeito”. (BARROS, 2010, p. 337)

Nesse sentido, destacamos as potências subversivas expressas pela imagem desse feminino ao promover uma ruptura com pensamento binário. Contudo, ao analisarmos suas ligações com a escravização, a hiperssexualização e a marginalidade, identificamos pistas de como a sociedade brasileira percebeu e percebe um feminino marcado pela raça e pelo gênero. Acerca da erotização e hipersexualização de Pombagira, mostra-nos Silva que: "[...] este imaginário, em muitos casos, reproduz, no plano mítico, o poder de sedução atribuído às mulheres negras e mulatas, cuja sensualidade e erotização foram apanágios da visão deturpada impingida pela sociedade brasileira às mulheres africanas e posteriormente mestiças no regime escravocrata e no contexto urbano pós-abolição.” (SILVA, 2015, p. 80).

A partir de tais reflexões, podemos observar algumas produções de sentido que dialogam conjugando raça e gênero, promovendo múltiplas formas de opressões onde o feminino desperta desejos e violências. Um imaginário que mescla: "Sofrimento e prazer, resignação e gozo: a combinação é ligada a representação do feminino. Suas conotações acionam estereótipos da mulher, do negro e do índio da tradição cultural, cuja síntese densa é a mulher mestiça, sexualmente disponível e sem grandes ambições ou capacidades produtivas." (SOVIK, 2009, p. 43).

Tendo em vista as discussões feitas acerca da produção das imagens de Pombagira no imaginário popular, dialogando com trechos de pontos cantados, no próximo item analisamos três músicas populares brasileiras que têm como personagem principal a Pombagira em suas letras, no intuito de demonstrar de que modo a construção de sentido em torno dessa figura feminina é produzida pelas vozes que interagem.

\title{
5 ÁGUAS QUE SE ENCONTRAM? A FIGURA DA POMBAGIRA NA MPB
}

E que imagens da figura da Pombagira têm possibilidade de ser produzidas em músicas populares brasileiras? Nossa hipótese é que as tramas da MPB, fruto cultural do nacionalismo, parecem classificar pejorativamente a figura do feminino (representada pela Pombagira), classificação esta que é produzida sempre em relação à figura do masculino. A voz é dada ao masculino para falar, para aconselhar, para prevenir os outros dos perigos que a figura feminina representa. 
Quando a Pombagira é locutora, ele acaba por se definir reforçando o lugar de transgressora imoral. Embora as canções tragam marcas das heranças afro-ameríndias, como o uso de palavras e/ou expressões africanas, tais referências descrevem o exótico, o "anormal", aquilo que se configura fora dos padrões estabelecidos.

Escolhemos para essas análises as letras das obras “Moça bonita”, de Jair Amorim e Evaldo Gouveia; "Sob medida”, de Chico Buarque de Hollanda e "Coisa feita”, de João Bosco e Aldir Blanc.

Os primeiros vestígios para a realização desse trabalho foram apontados em uma pesquisa de campo, por uma médium que afirmava ser "Sob medida" a música preferida de uma Pombagira, uma vez que, de acordo com ela, sempre que realizava seus trabalhos, a Pombagira solicitava que a música fosse cantada. A justificativa pela opção era a empatia da entidade com a letra da canção. Em suas palavras, aquela era a sua música. Sendo assim, o que a princípio causou estranhamento por borrar as fronteiras entre sagrado e profano, posteriormente descortinou novos horizontes.

No tocante às obras "Moça formosa" e "Coisa feita", seguimos os vestígios fornecidos pelas investigações de Prandi (2005), que relacionou 761 canções da MPB que remetem a elementos religiosos afro-brasileiros. Após recolher tais dados, realizamos um processo de desacostumação (CAPUTO, 2012) dos ouvidos onde reconhecemos componentes que formam as imagens de Pombagira.

Na canção "Moça bonita”, gravada, em 1976, por Ângela Maria, uma das mais populares cantoras do país, pode ser identificada uma simbiose entre música e religiosidade, sobretudo por narrar os ritos do culto à Pombagira ("girando, girando"), em conformidade ao andamento do compasso ascendente da composição, por meio do uso de instrumentos de percussão (tambores, atabaques). A relação é tão estreita que a obra ganhou novas versões e foi incorporada ao repertório oficial dos cultos de Pombagira.

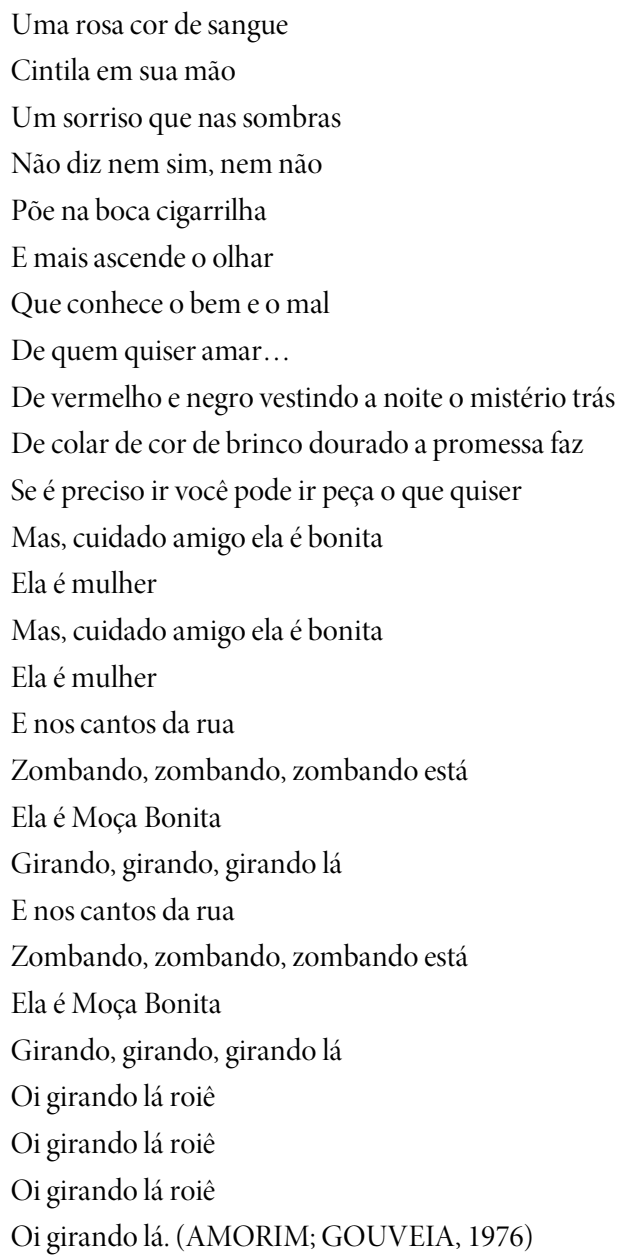


A canção apresenta aos coenunciadores um dos cenários habituais de localização da Pombagira, as ruas, e constrói uma descrição sobre ela, sobre seus gestos, sobre seus atributos físicos. Vê-se que a descrição ressalta características do corpo de Pombagira - mão, sorriso, boca, olhar - relacionadas à conotação sexual. As descrições que confirmam esse caráter ao longo da canção criam uma imagem de Pombagira associada à sedução - aspecto ressaltado pela a cor vermelha -, à experiência de vida amorosa - "conhece o bem e o mal de quem quiser amar" -, à indefinição de suas escolhas - "não diz nem sim nem não". Elementos simbólicos utilizados nos rituais religiosos também agregam à cena o caráter sedutor de Pombagira, tal como a rosa vermelha, amplamente utilizada nos rituais como elemento mágico e associada à sexualidade (WALKER, 1988), à cigarrilha, ao colar e ao brinco, que funcionam como signos que remetem à vaidade e ao luxo.

As vestes constituem marcas relevantes na elaboração dessa imagem, sendo, frequentemente, vermelhas e pretas, cores que aludem ao sangue, às sombras, à noite e que remetem à negatividade no imaginário popular. Outras pistas linguísticas que podemos associar ao "mal", ao "negativo" são ironia e sarcasmo, referências pouco explícitas em figuras de religiões de origem europeia. A sensualidade e a maneira particular de interagir com o corpo estão registradas na maneira como esse feminino dança/gira.

Na sequência da canção, após esse percurso descritivo da figura feminina por um locutor que está exterior à cena enunciativa, a enunciação passa a se transformar em um discurso de advertência, baseado nos perigos que essa figura, sendo mulher e bonita, poderia oferecer aos homens: "Mas cuidado amigo, ela é bonita, ela é mulher".

O operador adversativo "mas" nesse trecho tem um comportamento pragmático interessante: ele instaura uma refutação ao que fora dito anteriormente, e não funciona apenas como uma simples oposição, como costumam ser descritos nas gramáticas tradicionais: "Se é preciso ir você pode ir peça o que quiser/Mas, cuidado amigo ela é bonita/ela é mulher". Vejamos que, neste caso, há um afrontamento entre o locutor e um destinatário (real ou fictício), e não uma simples oposição entre dois enunciados. Segundo Maingueneau, com base em Ducrot (MAINGUENEAU, 1997, p. 166), "o mas de refutação recusa a legitimidade daquilo que um destinatário disse ou pensou, ou poderia ter dito ou pensado".

Em "Sob medida", música de Chico Buarque de Hollanda (1976), identificamos no locutor feminino marcas que nos remetem à sensualidade, carisma e vulgaridade, alimentado, como já dito, uma visão negativa de mulher que não segue as "normas de identidade" da sociedade em questão.

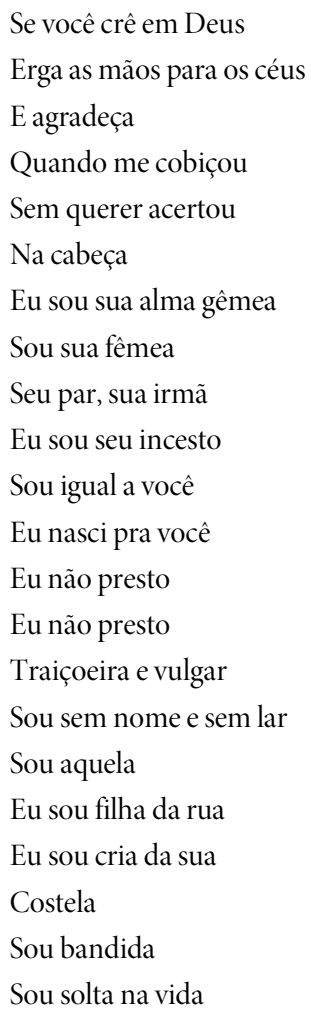




\author{
E sob medida \\ Pros carinhos seus \\ Meu amigo \\ Se ajeite comigo \\ E dê graças a Deus \\ Se você crê em Deus \\ Encaminhe pros céus \\ Uma prece \\ E agradeça ao Senhor \\ Você tem o amor \\ Que merece
}

Diferente da canção anterior, "Sob medida" não trata da Pombagira por meio da presença de locutores exteriores à cena que a descrevem e falam sobre e por ela. Pombagira como locutora fala por si só, é ela mesma a sua voz, é locutora. No entanto, apesar de se autodescrever, encontramos marcas por meio das quais podemos identificar um afastamento de uma norma social hegemônica. Nos trechos: "Eu não presto/Traiçoeira e vulgar/ Sou sem nome e sem lar", a negação nos dá pistas sobre o que está sendo pressuposto, ao pôr em cena um "enunciador" que sustentaria que há pessoas que "prestam", que têm "nome" e que têm "lar". Quando ela diz que não presta, está pressupondo que deveria prestar, revelando assim a existência de uma norma de conduta, da qual ela não faz parte.

Estabelece-se aqui um diálogo com Ducrot (1987 p. 202), para quem grande parte dos enunciados negativos pode ser analisável como encenação do choque entre duas atitudes antagônicas, atribuídas a dois enunciadores diferentes: "o primeiro personagem assume o ponto de vista rejeitado e o segundo, a rejeição deste ponto de vista”.

O fato de haver uma sequência de explicações morais que encaminham a justificativa, motivo pelo qual a Pombagira não presta, evidencia-nos uma norma de identidade feminina, que não é a que ela segue, visto que é "traiçoeira", "vulgar", "filha da rua", "bandida", "solta na vida”. Nesse sentido, percebe-se que, ao se autodescrever, "a locutora” reafirma e reforça papéis do que é bom e ruim, do que deve e não deve ser feito.

A referência a aspectos da cultura e dos rituais religiosos de matriz africana não aparecem de modo explícito na canção, em comparação com a canção anterior. Menções a essas religiões foram completamente apagadas e, portanto, a letra comportaria qualquer locutor feminino, que não necessariamente a Pombagira.

"Coisa feita", a última canção por nós analisada foi composta João Bosco e Aldir Blanc, em 1982, e se assemelha à canção anterior pelo modo como a locutora feminina (Pombagira) está inserida no texto: a ela é dada voz para falar sobre si mesma. No entanto, percebemos que as referências às religiões, cultura e rituais de matrizes africanas são bem mais explícitas do que na canção anterior.

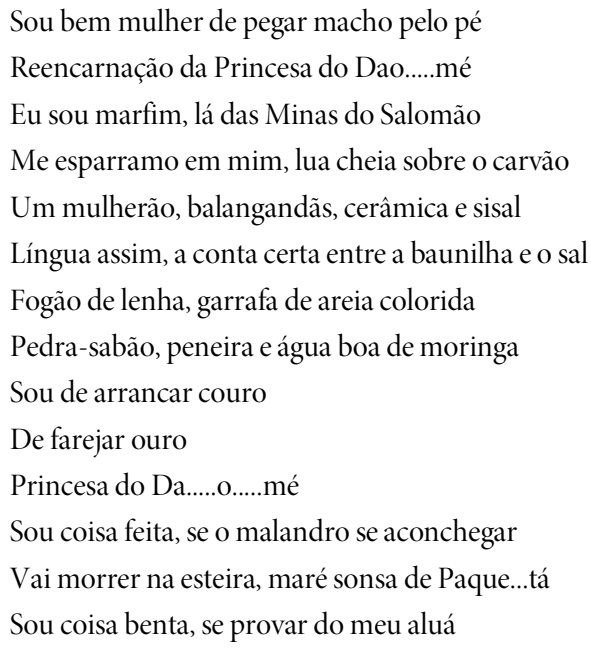




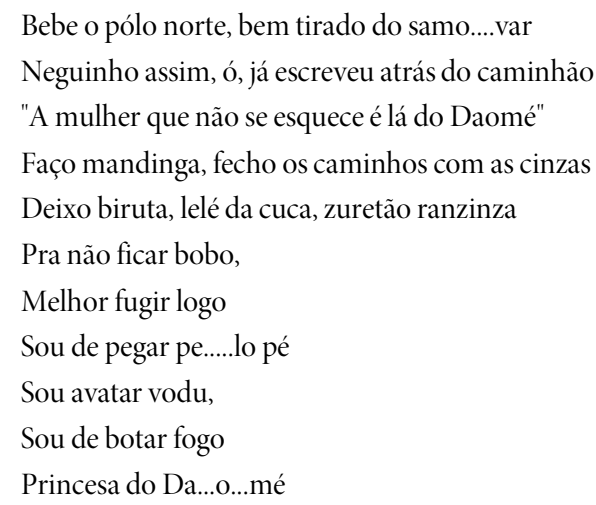

A música nos apresenta uma locutora feminina, que fala sobre si mesma de modo provocador e ameaçador: "Sou de pegar pelo pé", "Sou de botar fogo", "deixo biruta, lelé da cuca, zuretão ranzinza", "faço mandinga, fecho os caminhos com as cinzas", o que mostra outra face da mulher, que não é mais submissa aos desejos dos homens, que é capaz de manipular esses desejos e que se vangloria desse poder, sobretudo com o reconhecimento da figura masculina: "Neguinho assim, ó, já escreveu atrás do caminhão/ "A mulher que não se esquece é lá do Daomé"”. Percebe-se, portanto, que apesar do investimento no locutor que parece se assumir em uma postura controladora, ela ainda necessita da figura masculina para se sentir nesse lugar, o que demonstra que as figuras femininas continuam sendo definidas por meio da figura masculina, pois é ela que as autorizam a ser desse modo.

Os elementos da cultura, rituais e religiões de matriz africana aparecem nas referências marcadamente nacionais, tais como "pedrasabão", "aluá" e "princesa do Daomé"

Percebem-se ainda pistas que nos remetem ao hibridismo que permeia essa identidade. Por exemplo, quando se diz "Sou coisa feita e Sou coisa benta" verificamos uma naturalização do sincretismo presente em nossas terras, destacando elementos da religião que se materializam de modos diversos: na reencarnação, na mandinga, no vodu.

Ainda nesse sentido, iluminamos uma questão que nos pareceu relevante destacar: o fato de na primeira e na terceira canções haver a referência direta às religiões de matrizes africanas como uma religião que pune, que é vingativa. Ao passo que na segunda canção, há a existência de um deus, que parece cristão, a quem se deve agradecer. Nota-se que a segunda canção é a que mais apagou as referências aos elementos culturais, religiosos e ritualísticos das matrizes africanas, o que nos leva a concluir que os elementos negativos, pejorativos e menos valorizados pela sociedade estejam relacionados a estas religiões, apontando um inquestionável preconceito com relação a estas.

\section{CONSIDERAÇÕES FINAIS}

Buscamos, neste artigo, analisar os modos de produção de sentido da imagem de uma das entidades mais populares das religiões afro-brasileiras - a Pombagira -, por meio da observação de três canções da MPB. Dessa forma, mediante o exame de obras disponíveis em acervos digitalizados, identificamos marcas de carga pejorativa e etnocêntrica, historicamente atribuídas ao feminino e às culturas afro-ameríndias, fato que reforça a produção de um lugar estigmatizado para estes. Pombagira é híbrida e sincrética, o que representa uma ruptura com os modelos vigentes tanto quanto aos aspectos culturais, quanto ao gênero.

Ao mesmo tempo, sua potência revolucionária ainda permanece aprisionada a sua sensualidade e à sexualidade, deixando para o futuro a criação de debates e produções que desconstruam estereótipos e aplaquem preconceitos. Nesse sentido, a marginalização desta imagem reconfirma e reproduz uma noção de que a cidadania deriva de um perfil de sujeito requerido pelo projeto de modernidade, não acessível a todos. Ao mesmo tempo em que a música contribui para a divulgação de Pombagira à população, ela reforça estigmas. Portanto, consideramos relevante analisar o que conferiu plausibilidade autoevidente a esse sistema cultural de 
base nacionalista e de criação de uma identidade brasileira, e ao mesmo tempo, destacar elementos-chave na decomposição dos mesmos.

Por fim, observamos que as canções recortadas para este fim, ao mesmo tempo em que dão visibilidade às religiões de matriz africana, publicizando-as, acabam reforçando preconceitos, sobretudo em torno da figura feminina transgressora na cena religiosa.

Pensamos que estudos como este promovem a desestabilização de paradigmas eurocêntricos e colaboram para uma visão emancipadora do feminino e das culturas subalternizadas. Acreditamos que a valorização das heranças afro-ameríndias deva ir além do aspecto de formação identitária nacional, reconhecendo sua sofisticação epistemológica e colaboração para consolidação de uma sociedade plural.

\section{REFERÊNCIAS}

AMARAL, R. ; SILVA, V. G. Foi conta para todo canto: as religiões afro-brasileiras nas letras do repertório popular brasileiro. AfroÁsia, v. 34, 189-235, 2006.

AUGRAS, M. De Iyá Mi a Pomba-gira: transformações e símbolos da libido. In: MOURA, C. E. M. (org.). Candomblé: religião do corpo e da alma: tipos psicológicos nas religiões afro-brasileiras. Rio de Janeiro: Pallas, 2000. p. 17-44.

AUSTIN, J. Quando dizer éfazer. Porto Alegre: Artes Médicas, 1990.

COUTINHO, E. (org.). O bazar global e o clube dos cavaleiros ingleses: textos seletos de Homi Bhabha. Rio de Janeiro: Rocco, 2011.

BAKHTIN, M. Marxismo e filosofia da linguagem. São Paulo: HUCITEC, 2006.

BAKHTIN, M.Estética da criação verbal. São Paulo: WMF Martins Fontes, 2011.

BARROS, M. L. Labareda, teu nome é mulher: análise etnopsicológica do feminino à luz de pombagiras. Ribeirão Preto, 2010.

CAPONE, S. A busca da África no Candomblé - tradição e poder no Brasil. Rio de Janeiro: Pallas, 2004.

CAPUTO, S. G. Educação nos terreiros: e como a escola se relaciona com crianças de candomblé. Rio de Janeiro: Pallas, 2012.

COSTA, S. A mestiçagem e seus contrários - etnicidade e nacionalidade no Brasil contemporâneo. In: Tempo Social; Rev. Sociol. USP, São Paulo, 13 (1):143-158, maio de 2001.

FOUCAULT, M. Vigiar e punir: nascimento da prisão. Petrópolis, Vozes, 2004.

HALL, S. . Pensando a Diáspora (Reflexões Sobre a Terra no Exterior). In: SOVIK, L (org.), Da Diáspora: identidades e mediações culturais. Belo Horizonte: Editora UFMG; Brasília: Representação da Unesco no Brasil, 2003. Disponível em: http://www.memoriasindical.com.br/lermais_materias.php?cd_materias=281 Acesso em 04 set. 2016

MaingueneAU, D. Novas tendências em Análise do Discurso. São Paulo: Pontes, 1997.

PINA, J. A. A música popular brasileira na construção do conhecimento em Saúde Pública: o tema processo de trabalho e saúde. Interface-Comunicação, Saúde, Educação, v.48, n.18, p. 87-100, 2014. 
PRANDI, R. Pombagira e as faces inconfessas do Brasil. In: PRANDI, R. Herdeiras do Axé. São Paulo, Hucitec, 1996. p. 139 -164.

PRANDI, R Orixás na música popular brasileira: Diretório de 761 letras da MPB com referências a orixás e outros elementos das religiões afro-brasileiras. Período de 1902 a 2000. Disponível em: http://www.fflch.usp.br/sociologia/prandi/mpb-down.htm Acesso em: 05 dez. 2015.

SCHWARCZ, L.M. Nem preto nem branco, muito pelo contrário: cor e raça na intimidade. São Paulo : Claro Enigma, 2012.

SILVA, V. G. Exu: o guardião da casa do futuro. Rio de Janeiro: Pallas, 2015.

SIMAS, L A. Quem tem medo de Pombagira? Disponível em: http://hisbrasileiras.blogspot.com.br/2016/04/quem-tem-medo-dapombagira 7.html. Acesso em: 07 abr. 2016.

SOVIK, L. Aqui ninguém é branco. Rio de Janeiro: Aeroplano, 2009.

SOVIK, L.O rap desorganiza o carnaval: globalização e singularidade na música popular brasileira. CADERNO CRH, Salvador, n. 33, p. 247-255, jul./dez. 2000.

\section{(ㄷ) (1) $\circledast \ominus$}

Recebido em 23/12/2018. Aceito em 12/05/2019. 